\title{
Reinforcing Roles of Lady Health Workers in Sedayu Community Feeding Center: Six-Steps Program Planning and Evaluation
}

\author{
Bunga Astria Paramashanti, Sulistiyawati \\ Department of Nutrition, Faculty of Health Sciences \\ Universitas Alma Ata, Yogyakarta \\ E-mail: bunga@almaata.ac.id
}

\section{Article History: \\ Received: April $4^{\text {th }} 2020$ \\ Revised: Aug 12 2020 \\ Accepted: Nov 30 2020}

Keywords: lady health workers, cadres, community-based nutrition program, community feeding centers, nutrition, capacity building.

\begin{abstract}
Child malnutrition remains a challenge in Indonesia's public health nutrition field. The assistance of lady health workers child feeding centers becomes important to guard nutritional issues among children in the community. To reinforce the roles of lady health workers in the community feeding center, we recruited lady health workers in two community feeding centers of Argodadi and Argorejo villages, Sedayu Subdistrict, Bantul District, in a capacity-building intervention. We were hoping that lady health workers with adequate knowledge and skills can contribute more effectively in the community-based nutrition program including nutritional status assessment and monitoring, nutrition counseling and promotion, general food supplementation, and referral system. This program was effective to increase maternal knowledge of infant and young child feeding, to improve energy and protein intakes of the children, and to add the bodyweight of the children.
\end{abstract}

\section{Introduction}

Malnutrition contributes to mortality, morbidity, and disability. This may also impact the productivity, performance, and economic development in a country. The immediate causes of malnutrition are poor dietary intake and infections which are raised from inadequate care, poor health services, and food insecurity. ${ }^{1}$ To prevent and to control nutritional problems, nutrition actions aimed to eliminate these causes are needed.

Community health workers hold important roles in improving child nutrition. Based on Shrimpton and Vaidyananthan, community health workers main responsibilities include the monthly-based weighing of children, counselling, home visits to children who missed the regular weighing, and referral of children with malnutrition

${ }^{1}$ Robert E Black et al., "Maternal and Child Undernutrition: Global and Regional Exposures and Health Consequences.," Lancet (London, England) 371, no. 9608 (January 2008): 243-260. 
or any other health impairment. ${ }^{2}$ In Indonesia, community health workers are mainly female working as Posyandu cadres.

Posyandu is an integrated health post covering maternal and child health, family planning, immunization, and nutrition services. ${ }^{3}$ Iswarawanti stated in her paper that Posyandu cadres are the bridge between health professionals and the community to achieve the population health. ${ }^{4}$ Compared to Posyandu that implements its program for all children under-fives, the community feeding center is a community-based feeding center that delivers a nutritional program for malnourished children.

There are two community feeding centers under the coverage area of Sedayu II Primary Health Center (Puskesmas Sedayu II). As our previous publication, these feeding centers activities included nutritional assessment, general food supplementation, and group education. These activities were held every week and assisted by regular Posyandu cadres and either a nutritionist or a midwife. The target of programs were children under-fives with malnutrition. When there was a budget constraint, the priority was given to wasted children (weight-for-height Z-score below -2 SD) and poor families. ${ }^{5}$ Therefore, we aimed to strengthen the community-based nutrition program within the community feeding centers in Sedayu II Primary Health Center by reinforcing roles of lady health workers in program delivery through six-steps program planning.

\section{Method}

There were two community feeding centers in Sedayu II Primary Health Centers located in Argodadi and Argorejo villages. Previously, we conducted a capacity-building intervention to 14 lady health workers. A 3-day mini-seminar was held to deliver updated messages on infant and young child feeding as stated in our previous publication. ${ }^{6}$ Trained lady health workers in the local villages where the community feeding center held were all involved in this community-based nutrition program which was conducted between January and September 2017.

The community-based nutrition program in this paper was based on the six-steps

\footnotetext{
2 Roger Shrimpton and Shantha Vaidyananthan, "Community Based Nutrition Programs - Critical Design Elements and Research Needs," World Nutrition 8, no. 1 (2017): 41.

${ }^{3}$ Health Promotion Center, Ayo Ke Posyandu, Indonesia Demographic and Health Survey (Jakarta: Ministry of Health of Indonesia, 2012); Emma Rachmawati et al., "Optimalisasi Promosi Kesehatan Rumah Sakit Dalam Mewujudkan Gerakan Masyarakat Hidup Sehat Berkemajuan Di Rumah Sakit Muhammadiyah," Engagement : Jurnal Pengabdian Kepada Masyarakat 3, no. 1 (2019): 80-91.

4 Dwi Nastiti Iswarawanti, "Kader Posyandu: Peranan Dan Tantangan Pemberdayaannya Dalam Usaha Peningkatan Gizi Anak Di Indonesia," Jurnal Manajemen Pelayanan Kesehatan 13, no. 04 (2010): 169-173.

5 Bunga Paramashanti and Sulistyawati Sulistyawati, "Pengaruh Integrasi Intervensi Gizi Dan Stimulasi Tumbuh Kembang Terhadap Peningkatan Berat Badan Dan Perkembangan Balita Kurus," Jurnal Gizi Klinik Indonesia 15, no. 1 (2018): 16.

${ }^{6}$ Ibid.
} 
program planning and evaluation. We adopted the six-steps in quality intervention development by Wight et al. These steps include defining the problem, contextualization, change mechanism, program delivery, small-scale trial, and evaluation. ${ }^{7}$ Thus, we implemented all these steps into the community feeding center program. Table 1 presents the six-steps program planning and evaluation and specific questions.

Table 1. A Modified Wight's Six-Steps Intervention Development

\begin{tabular}{|c|c|c|}
\hline No & Steps & Questions \\
\hline \multirow[t]{4}{*}{1.} & Defining the problem & What is the problem? \\
\hline & and its causes & $\begin{array}{l}\text { What are the causes at individual, interpersonal, } \\
\text { community and sociocultural levels? }\end{array}$ \\
\hline & & Which are the most important causes? \\
\hline & & $\begin{array}{l}\text { What are the impacts for directly and indirectly affected } \\
\text { population? }\end{array}$ \\
\hline \multirow[t]{2}{*}{2.} & Contextualization & $\begin{array}{l}\text { Which factors or causes are most modifiable or have the } \\
\text { likelihood to be changed? }\end{array}$ \\
\hline & & $\begin{array}{l}\text { Which program/intervention that has been effective in } \\
\text { solving the problem? }\end{array}$ \\
\hline \multirow[t]{3}{*}{3.} & Change mechanism & How to achieve the change to address the problem? \\
\hline & & $\begin{array}{l}\text { Which program/intervention that can give short-term } \\
\text { or long-term outcomes? }\end{array}$ \\
\hline & & $\begin{array}{l}\text { Is the program/intervention sufficient to reduce the } \\
\text { problem? }\end{array}$ \\
\hline \multirow[t]{8}{*}{4.} & $\begin{array}{l}\text { Designing the } \\
\text { program }\end{array}$ & $\begin{array}{l}\text { What is the most suitable community unit to deliver the } \\
\text { program (e.g., primary health center, posyandu, feeding } \\
\text { center, hospital)? }\end{array}$ \\
\hline & & $\begin{array}{l}\text { Do you need to involve the community in your program } \\
\text { (e.g., parent groups, community leader, community } \\
\text { health workers)? In which aspect do you need them to } \\
\text { be involved? }\end{array}$ \\
\hline & & Who will deliver the program in the field? \\
\hline & & What training is required? \\
\hline & & What is the frequency of the program? \\
\hline & & What is the duration of the program? \\
\hline & & $\begin{array}{l}\text { Do you need data collection before, during, and after the } \\
\text { program being delivered? If yes, how will you collect } \\
\text { the data? }\end{array}$ \\
\hline & & $\begin{array}{l}\text { To whom and how do you disseminate the } \\
\text { results/recommendations? }\end{array}$ \\
\hline \multirow[t]{4}{*}{5.} & Small-scale trial & Is the program feasible? \\
\hline & & $\begin{array}{l}\text { Do the community (and or health practitioners) accept } \\
\text { the program? }\end{array}$ \\
\hline & & How is the participation of the target groups? \\
\hline & & How to maximize the population to reach? \\
\hline
\end{tabular}

7 Daniel Wight et al., "Six Steps in Quality Intervention Development (6SQuID)," Journal of Epidemiology and Community Health 70, no. 5 (2015): 520-525. 
6. Evaluation

Which outcomes or processes do you need to evaluate?

Do you need a baseline and follow-up survey with the same group?

Do you need controls from the different group?

When the evaluation is conducted and by whom?

Do you need any statistical analysis?

\section{Results}

\section{Defining the Problem and its Causes}

Based on the Bantul District Health Profile 2016, the prevalence of severe acute malnutrition in Sedayu Subdistrict was the highest $(0.81 \%)$ amongst all subdistricts. ${ }^{8}$ Previous studies conducted within the subdistrict also showed that there were problems related to complementary feeding ${ }^{9}$ and child growth ${ }^{10}$ and development ${ }^{11}$. These indicated the complexity of nutritional issues in this paper which is around child feeding (e.g., breastfeeding, dietary diversity, the timing of complementary feeding, and overall dietary quality and quantity) and nutritional status (e.g., stunting, wasting, severe acute malnutrition).

Child undernutrition may exist in various forms such as stunting, underweight, wasting, micronutrient deficiencies, and suboptimum feeding practices. Based on the maternal and child malnutrition framework, the immediate causes of child undernutrition are inadequate dietary intake and infections, whereas the underlying causes include low quality of care, lack of health services, and household food insecurity. Child undernutrition becomes a serious problem as it contributes to mortality, morbidity, and disability. This may also impact the productivity, performance, and economic development in a country. ${ }^{12}$

${ }^{8}$ Department of Health of Bantul District, Bantul District Health Profile (Bantul: Department of Health of Bantul District, 2016), http://dinkes.bantulkab.go.id/filestorage/dokumen/2016/08/narasi profil 2016.pdf.

${ }^{9}$ Dwi Puji Khasanah, Hamam Hadi, and Bunga Astria Paramashanti, “Waktu Pemberian Makanan Pendamping ASI (MP-ASI) Berhubungan Dengan Kejadian Stunting Anak Usia 6-23 Bulan Di Kecamatan Sedayu," Jurnal Gizi dan Dietetik Indonesia (Indonesian Journal of Nutrition and Dietetics) 4, no. 2 (2016): 105; Bunga Astria Paramashanti, Yhona Paratmanitya, and Marsiswati Marsiswati, "Individual Dietary Diversity Is Strongly Associated with Stunting in Infants and Young Children," Jurnal Gizi Klinik Indonesia 14, no. 1 (2017): 19.

10 Yeyen Supriyanto, Bunga Astria Paramashanti, and Dewi Astiti, "Berat Badan Lahir Rendah Berhubungan Dengan Kejadian Stunting Pada Anak Usia 6-23 Bulan," Jurnal Gizi dan Dietetik Indonesia (Indonesian Journal of Nutrition and Dietetics) 5, no. 1 (2018): 23.

${ }^{11}$ Kiki Nur Meylia et al., "Fine Motor, Gross Motor, and Social Independence Skills among Stunted and Non-Stunted Children," Early Child Development and Care 0, no. 0 (2020): 1-8, https://doi.org/10.1080/03004430.2020.1739028.

${ }^{12}$ UNICEF, "Strategy for Improved Nutrition of Children and Women in Developing Countries," The Indian Journal of Pediatrics 58 (1991): 13-24; Black et al., "Maternal and Child Undernutrition: Global and Regional Exposures and Health Consequences." 


\section{Contextualization}

As shown in Figure 1, we identified four programs within the community feeding center which were nutritional assessment and monitoring, counselling and promotion of infant and young child feeding (IYCF), general food supplementation, and referral system. Having discussed with a local nutritionist in the Sedayu 2 Primary Health Center, there were two community feeding centers which were held regularly every week in two villages. However, we found that there was no specific guideline on delivering nutrition program in the community feeding centers. The available guidelines which had been used were only separated guidelines from regular nutrition program. In every program within the community feeding center, lady health workers (cadres) were involved and having interaction directly with mothers or caregivers of the children. We also identified that there was a need to build and to refresh the lady health workers' capacity with the most updated materials and promptly. A success story from Thailand ${ }^{13}$ which can be learned to eradicate child undernutrition is to improve the quality of primary health care access and to deliver an effective community-based nutrition program.

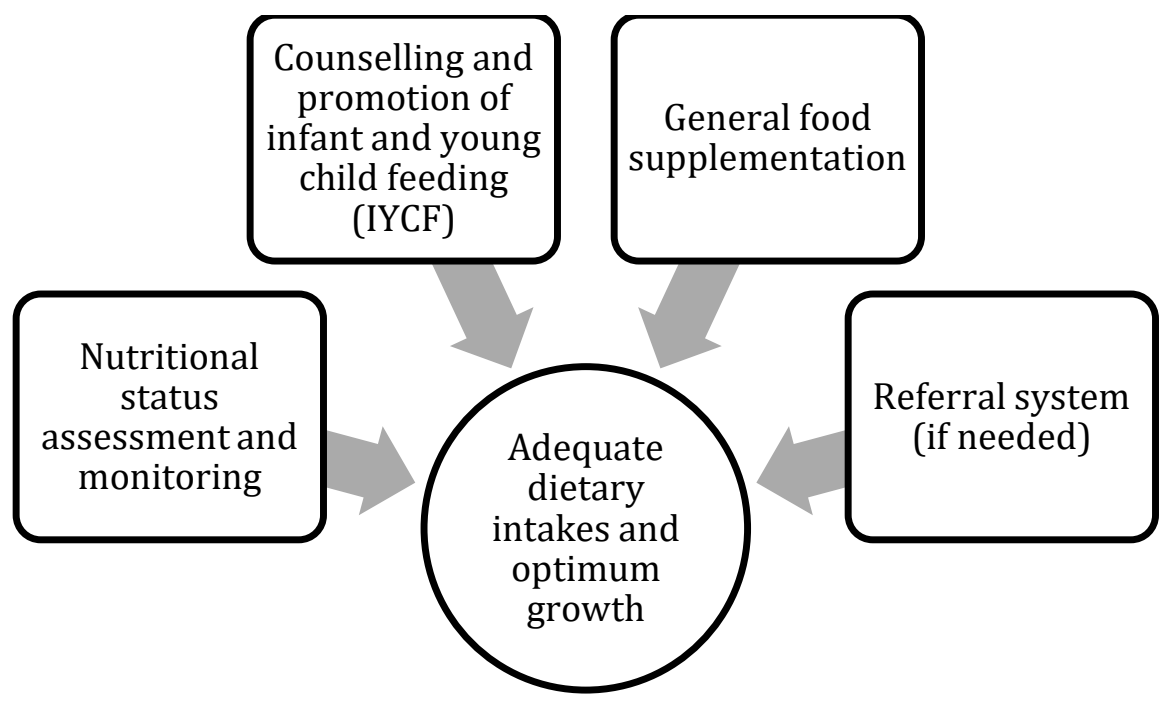

Figure 1. Community-based Nutrition Program in the Community Feeding Center

\section{Change Mechanism}

To combat child undernutrition, reinforcing the roles of lady health workers in a community-based nutrition program such as in Sedayu community feeding centers is of

${ }^{13}$ Pattanee Winichagoon, "Thailand Nutrition in Transition: Situation and Challenges of Maternal and Child Nutrition," Asia Pacific journal of clinical nutrition 22, no. 1 (2013): 6; Arief Andriyanto, Etty Rekawati, and Dwi Cahya Rahmadiyah, "Pemberdayaan Pada Penderita Diabetes Tipe 2 Dan Kader Kesehatan Dalam Pelaksanaan Program Pos Binaan Terpadu Penyakit Tidak Menular (Posbindu PTM)," Engagement: Jurnal Pengabdian Kepada Masyarakat 4, no. 1 (2020): 201-211. 
highly important. As lady health workers were part of the community itself, it would not be difficult for them to facilitate the community-based nutrition program to mothers or caregivers.

Thus, the targeted short-term outcomes are to improve nutritional knowledge, attitude, and behaviours of mothers or caregivers. When mothers or caregivers have adequate knowledge, positive attitude, and implement infant and young child feeding advice, the long-term outcome can also be achieved. The long-term incomes are improved child nutritional status.
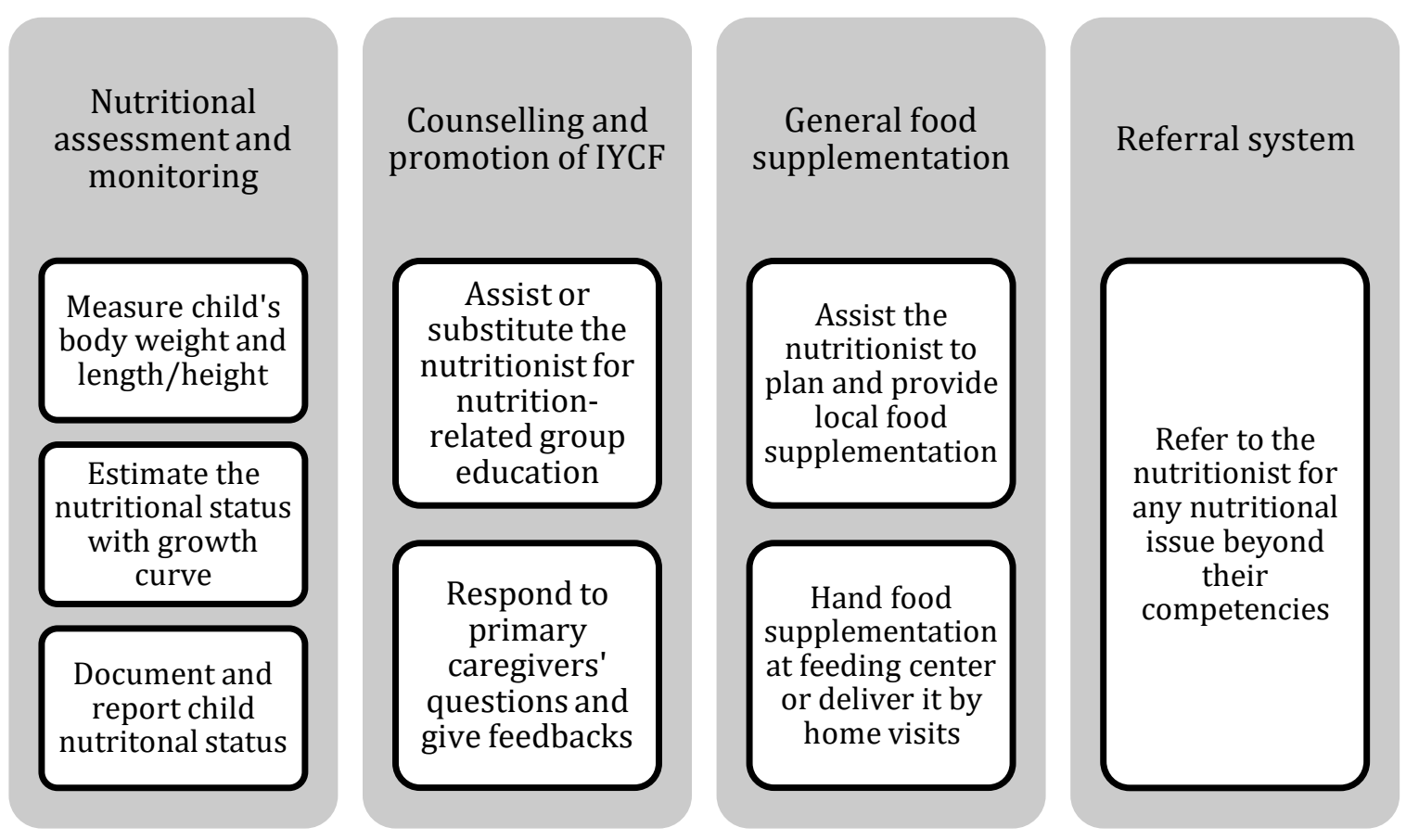

Figure 2. Roles of Lady Health workers in the Community-based Nutrition Program in Community Feeding Centers

\section{Designing the program}

Based on the defined problem of child undernutrition issues, we proposed a program of reinforcing roles of lady health workers in a community-based nutrition program where Sedayu community feeding centers were the selected community unit of program delivery. Targets of this program were lady health workers to own adequate knowledge and skills of nutritional assessment and infant and young child feeding. Meanwhile, the beneficiaries of this program covered children under the age of five years old which were aimed to have adequate dietary intakes and normal nutritional status, mothers or caregivers who were expected to have improved knowledge, attitude, and skills related to child nutrition, and health care professionals who were benefited with the effectivity of program delivery by lady health workers (see Table 2). 
In the planning and implementation of the program, we asked the involvement of a nutritionist and a midwife from Sedayu 2 primary health center, lady health workers, and mothers or caregivers of the children. Four programs in the community-based nutrition program would be delivered by lady health workers under the supervision of a responsible nutritionist. Training of lady health workers was aimed to update and refresh the knowledge and skills of lady health workers in the nutritional assessment, nutrition education, general food supplementation, and referral system to the primary health center. Nutrition education materials referred to the guidelines from the Ministry of Health of Indonesia ${ }^{14}$ and PAHO/WHO${ }^{15}$.

Table 2. Details of Reinforcing Roles of Lady Health Workers Program

\begin{tabular}{|c|c|}
\hline $\begin{array}{l}\text { Program } \\
\text { description }\end{array}$ & $\begin{array}{l}\text { Reinforcing roles of lady health workers in the community-based } \\
\text { nutrition program }\end{array}$ \\
\hline Location & $\begin{array}{l}\text { Community feeding centers in Argodadi and Argorejo villages, } \\
\text { Sedayu Subdistrict, Bantul District, Daerah Istimewa Yogyakarta }\end{array}$ \\
\hline Frequency & : Bi-weekly \\
\hline Duration & : At least four weeks \\
\hline Activities & $\begin{array}{l}\text { Nutritional status assessment and monitoring, nutritional } \\
\text { education, general food supplementation, and referral system }\end{array}$ \\
\hline Targets & : Lady health workers \\
\hline \multirow[t]{3}{*}{ Beneficiaries } & : Children under the age of five years old \\
\hline & : Mothers or primary caregivers of children under-fives \\
\hline & $\begin{array}{l}\text { Nutritionist, midwives, and other health professionals in the } \\
\text { primary health centers }\end{array}$ \\
\hline \multirow[t]{4}{*}{ Outputs } & $\begin{array}{l}\text { To improve the quality of community-based nutrition program in } \\
\text { the community feeding centers }\end{array}$ \\
\hline & $\begin{array}{l}\text { To empower lady health workers with knowledge and skills on } \\
\text { nutritional assessment and infant and young child feeding }\end{array}$ \\
\hline & $\begin{array}{l}\text { : To increase knowledge, attitude, and behaviours of mothers or } \\
\text { primary caregivers on infant and young child feeding }\end{array}$ \\
\hline & $\begin{array}{l}\text { To improve the adequacy and the quality of infant and young } \\
\text { child feeding }\end{array}$ \\
\hline Outcomes & : To improve the nutritional status of children under-fives \\
\hline
\end{tabular}

The community-based nutrition program in community feeding centers was delivered in every two weeks following the regular schedule which was already set. Our program lasted in four weeks, however, because we involved lady health workers within our program, our goal is to have a long-lasting program even after our intervention is finished. This reason highlighted our concern about the sustainability of the program.

\footnotetext{
14 Depkes R I Depkes RI, Panduan Penyelenggaraan Pemberian Makanan Tambahan Pemulihan Bagi Balita Gizi Kurang (Jakarta: Ditjen Bina Gizi dan KIA, 2019).

15 World Health Organization, Guiding Principles for Feeding Non-Breastfed Children 6-24 Months of Age (Geneva, Switzerland: World Health Organization, 2005).
} 
Several studies ${ }^{16}$, had been conducted in Sedayu Subdistrict to help us understand the nutritional issues related to infants and young children. We also contacted a local nutritionist to deepen our understanding related to the existing program as well as secondary data assessment from Bantul Health Profile 2016. As the baseline data, we conducted pre-tests to both lady health workers and mothers or primary caregivers. For lady health workers, pre-test on baseline knowledge and skills on nutritional status assessment and infant and young child feeding was done just before the training session. For mothers or primary caregivers, pre-test on knowledge, attitude, and behavior of infant and young child feeding were done before the community-based nutrition program being delivered in the community feeding centers.

\section{Discussion}

We conducted a community-based nutrition intervention involving lady health workers as described in point-4. Details of the intervention can be accessed in our published article. ${ }^{17} \mathrm{~A}$ total of 19 children were included in our small-scale trial. These children joined a regular program bi-weekly going through routine nutritional assessment by trained lady health workers. All mothers were recalled for their child's food intake in the past 24-hour. After that, all mothers were gathered to have nutritional education which was provided with current evidence-based child nutrition materials. Before the end of the session, lady health workers handed a packaged of general food supplementation. Food supplementation was prepared based on the availability of local food (e.g., corn, rice, mung bean, egg, chicken, fruits) and processed food (e.g., fortified flour, fortified cooking oil, iodized salt) bought at local food vendors. All these activities were supervised by a nutritionist (3-year diploma level) from the primary health center and a nutritionist as well as a lecturer (master level) from Universitas Alma Ata. Motherchild pairs attended the program every week. If there was any missing session or mother and child had to leave the community feeding center before the session ended, lady health workers delivered the food supplementation and passed the educational messages by home visits. Overall, the program was highly accepted by mothers. This program was also fully supported by lady health workers, health practitioners, and head of Sedayu 2 primary health center.

For the use of evaluation of the program, both lady health workers and mothers or primary caregivers had to participate in the post-test session using the same questions

16 Paramashanti, Paratmanitya, and Marsiswati, "Individual Dietary Diversity Is Strongly Associated with Stunting in Infants and Young Children"; Supriyanto, Paramashanti, and Astiti, "Berat Badan Lahir Rendah Berhubungan Dengan Kejadian Stunting Pada Anak Usia 6-23 Bulan"; Khasanah, Hadi, and Paramashanti, "Waktu Pemberian Makanan Pendamping ASI (MP-ASI) Berhubungan Dengan Kejadian Stunting Anak Usia 6-23 Bulan Di Kecamatan Sedayu."

17 Paramashanti and Sulistyawati, "Pengaruh Integrasi Intervensi Gizi Dan Stimulasi Tumbuh Kembang Terhadap Peningkatan Berat Badan Dan Perkembangan Balita Kurus." 
as pre-tests described in point-4. Results of pre- and post-test scores were analyzed using paired t-test. Control group from posyandu regular program was also used to compare the results from the intervention group which later being analyzed with a two-sample ttest. Recommendations resulted from this program was shared with the community feeding center and primary health centers. Our published article also presents the results of this program. This program was effective to increase maternal knowledge of infant and young child feeding, to improve energy and protein intakes of the children, and to add the bodyweight of the children ${ }^{18}$.

\section{Conclusion}

Positive implications of community-based nutrition program can be achieved and sustained when community health workers are involved, provided with adequate training, and supports. This program is effective to improve maternal knowledge and dietary intakes and bodyweight of the children. However, we could not assess the nutritional status improvement due to the limited duration of the program. We could have examined the nutritional status and qualitative exploration of the program acceptability even after our program had finished because the regular program remained continued in the community feeding center. Future researchers or community programmers need to consider the amount of time of the community-based nutrition program which is relevant to the program's outcomes. This community-based nutrition program may be replicated in other community feeding centers and integrated health posts (posyandu) or other programs involving lady health workers.

\section{Acknowledgements}

This community service is part of the intervention-based research under Dosen Pemula 2016 research grant. We thank Indonesian Ministry of Research, Technology, and Higher Education; Sedayu 2 Primary Health Center (Puskesmas Sedayu 2), Sedayu Subdistrict, Bantul District, Daerah Istimewa Yogyakarta; and Alma Ata Center for Healthy Life and Food (ACHEAF) for the overall support of this program.

18 Ibid.; Syamsuar Abbas and Reflianto, "A Community Based Research: Building Healthy Living Community through Sports and Nutrition Program," Engagement: Jurnal Pengabdian Kepada Masyarakat 2, no. 2 (2018): 191-203; WHO, Essential Nutrition Actions: Improving Maternal, Newborn, Infant and Young Child Health and Nutrition (World Health Organization, 2013); Departement of Health of Bantul District, Bantul District Healt Profile (Bantul: Departemen of Health of Bantul District, 2016). 


\section{References}

Andriyanto, Arief, Etty Rekawati, and Dwi Cahya Rahmadiyah. "Pemberdayaan Pada Penderita Diabetes Tipe 2 Dan Kader Kesehatan Dalam Pelaksanaan Program Pos Binaan Terpadu Penyakit Tidak Menular (Posbindu PTM)." Engagement: Jurnal Pengabdian Kepada Masyarakat 4, no. 1 (2020): 201-211.

Black, Robert E, Lindsay H Allen, Zulfiqar A Bhutta, Laura E Caulfield, Mercedes de Onis, Majid Ezzati, Colin Mathers, and Juan Rivera. "Maternal and Child Undernutrition: Global and Regional Exposures and Health Consequences." Lancet (London, England) 371, no. 9608 (January 2008): 243-260.

Center, Health Promotion. Ayo Ke Posyandu. Indonesia Demographic and Health Survey. Jakarta: Ministry of Health of Indonesia, 2012.

Depkes RI, Depkes R I. Panduan Penyelenggaraan Pemberian Makanan Tambahan Pemulihan Bagi Balita Gizi Kurang. Jakarta: Ditjen Bina Gizi dan KIA, 2019.

District, Departement of Health of Bantul. Bantul District Healt Profile. Bantul: Departemen of Health of Bantul District, 2016.

Emma Rachmawati, Mochamad Iqbal Nurmansyah, Betty Semara Laksmi, Yuyun Umniyatun, and Lia Kharisma Saraswati. "Optimalisasi Promosi Kesehatan Rumah Sakit Dalam Mewujudkan Gerakan Masyarakat Hidup Sehat Berkemajuan Di Rumah Sakit Muhammadiyah." Engagement: Jurnal Pengabdian Kepada Masyarakat 3, no. 1 (2019): 80-91.

Iswarawanti, Dwi Nastiti. "Kader Posyandu: Peranan Dan Tantangan Pemberdayaannya Dalam Usaha Peningkatan Gizi Anak Di Indonesia." Jurnal Manajemen Pelayanan Kesehatan 13, no. 04 (2010): 169-173.

Khasanah, Dwi Puji, Hamam Hadi, and Bunga Astria Paramashanti. "Waktu Pemberian Makanan Pendamping ASI (MP-ASI) Berhubungan Dengan Kejadian Stunting Anak Usia 6-23 Bulan Di Kecamatan Sedayu." Jurnal Gizi dan Dietetik Indonesia (Indonesian Journal of Nutrition and Dietetics) 4, no. 2 (2016): 105.

Meylia, Kiki Nur, Tri Siswati, Bunga Astria Paramashanti, and Febrina Suci Hati. "Fine Motor, Gross Motor, and Social Independence Skills among Stunted and NonStunted Children." Early Child Development and Care 0, no. 0 (2020): 1-8. https://doi.org/10.1080/03004430.2020.1739028.

Organization, World Health. Guiding Principles for Feeding Non-Breastfed Children 6-24 Months of Age. Geneva, Switzerland: World Health Organization, 2005.

Paramashanti, Bunga Astria, Yhona Paratmanitya, and Marsiswati Marsiswati. "Individual Dietary Diversity Is Strongly Associated with Stunting in Infants and Young Children." Jurnal Gizi Klinik Indonesia 14, no. 1 (2017): 19.

Paramashanti, Bunga, and Sulistyawati Sulistyawati. "Pengaruh Integrasi Intervensi Gizi 
Dan Stimulasi Tumbuh Kembang Terhadap Peningkatan Berat Badan Dan Perkembangan Balita Kurus." Jurnal Gizi Klinik Indonesia 15, no. 1 (2018): 16.

Shrimpton, Roger, and Shantha Vaidyananthan. "Community Based Nutrition Programs Critical Design Elements and Research Needs.” World Nutrition 8, no. 1 (2017): 41.

Supriyanto, Yeyen, Bunga Astria Paramashanti, and Dewi Astiti. "Berat Badan Lahir Rendah Berhubungan Dengan Kejadian Stunting Pada Anak Usia 6-23 Bulan." Jurnal Gizi dan Dietetik Indonesia (Indonesian Journal of Nutrition and Dietetics) 5, no. 1 (2018): 23.

Syamsuar Abbas, and Reflianto. "A Community Based Research: Building Healthy Living Community through Sports and Nutrition Program." Engagement: Jurnal Pengabdian Kepada Masyarakat 2, no. 2 (2018): 191-203.

UNICEF. "Strategy for Improved Nutrition of Children and Women in Developing Countries." The Indian Journal of Pediatrics 58 (1991): 13-24.

WHO. Essential Nutrition Actions: Improving Maternal, Newborn, Infant and Young Child Health and Nutrition. World Health Organization, 2013.

Wight, Daniel, Erica Wimbush, Ruth Jepson, and Lawrence Doi. "Six Steps in Quality Intervention Development (6SQuID)." Journal of Epidemiology and Community Health 70, no. 5 (2015): 520-525.

Winichagoon, Pattanee. "Thailand Nutrition in Transition: Situation and Challenges of Maternal and Child Nutrition." Asia Pacific journal of clinical nutrition 22, no. 1 (2013): 6 . 